\title{
R
}

Writing about Byzantium: The History of Niketas Choniates

Theresa Urbainczyk

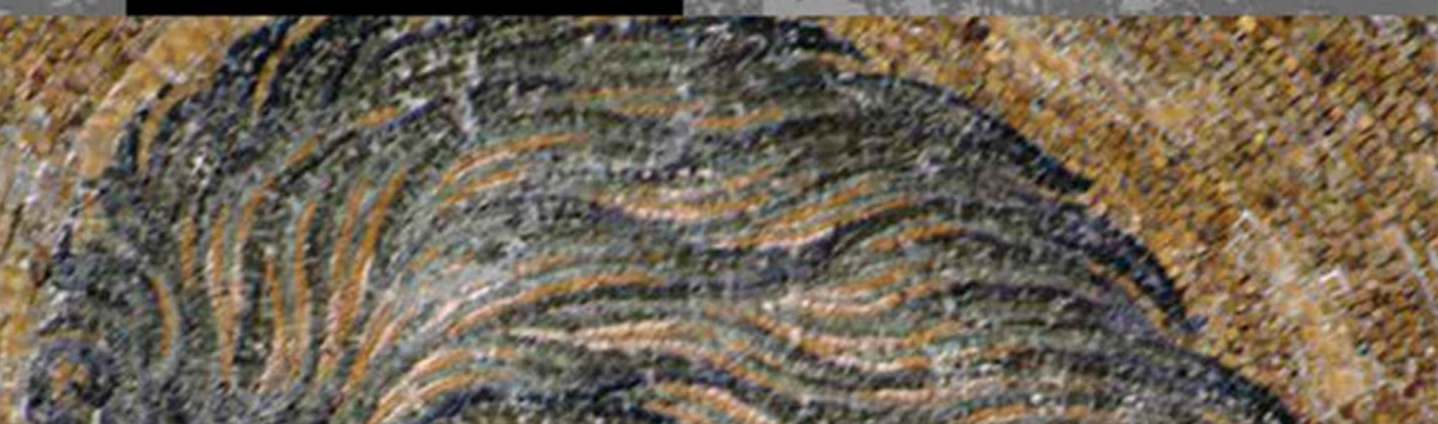

(1)
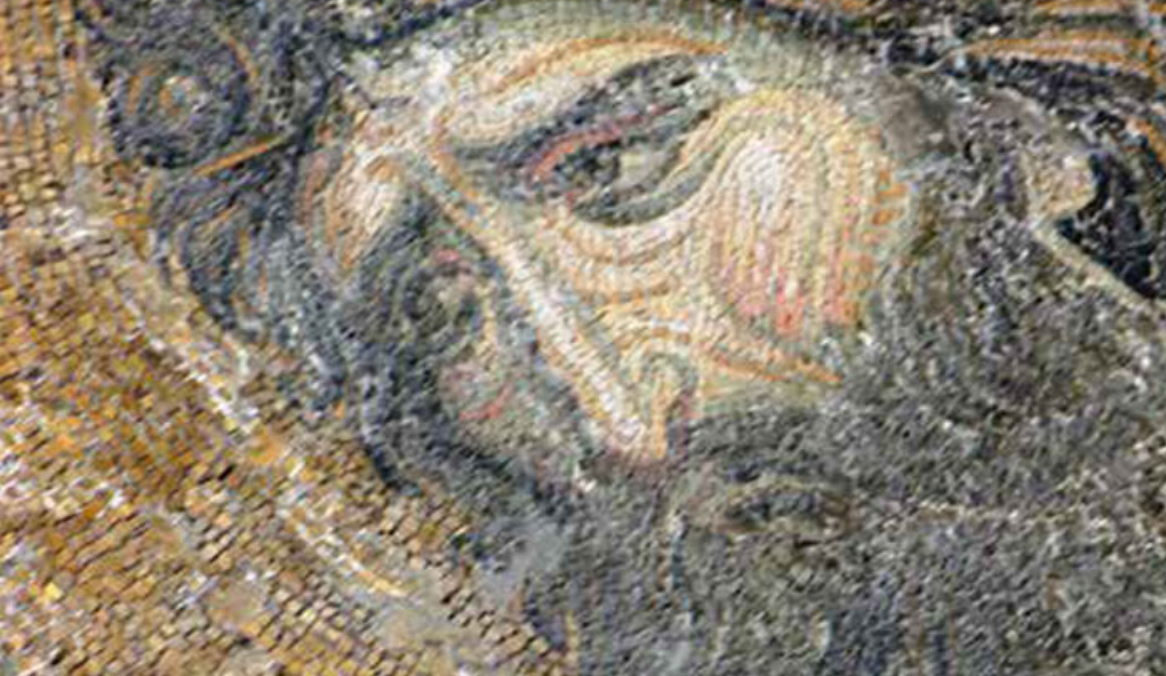


\section{Writing About Byzantium}

Niketas Choniates was in Constantinople when it was burnt and looted by the soldiers of the Fourth Crusade and he wrote a history which has always been the mainstay for anyone wishing to learn about the Comnene dynasty and the Byzantine Empire of the twelfth century. Yet it is a very difficult and puzzling text and, given its significance for the period, is understudied. The author says at the start that he wrote his work hoping that even workers and women would be able to profit from it, yet he wrote those words, and the rest of the history, in a highly convoluted, literary and at times opaque style and language.

This examination is an introduction to the history of Niketas, and to the author's views of why this period saw such catastrophe for the Byzantines. It looks at Niketas' thoughts about history-writing, the emperors, and the Comnene dynasty in particular, about the presence of God in man's affairs, and the historian's attitudes to the women of the imperial family.

Theresa Urbainczyk taught in the School of Classics, University College Dublin from 1992 to 2017. She is the author of Socrates of Constantinople: Historian of Church and State (1997), Theodoret of Cyrrhus: The Bishop and the Holy Man (2002), Spartacus (2004), and Slave Revolts in Antiquity (2008). 


\section{Birmingham Byzantine and Ottoman Studies General Editors \\ Leslie Brubaker, \\ Rhoads Murphey and \\ John Haldon}

Birmingham Byzantine and Ottoman Studies is devoted to the history, culture and archaeology of the Byzantine and Ottoman worlds of the East Mediterranean region from the fifth to the twentieth century. It provides a forum for the publication of research completed by scholars from the Centre for Byzantine, Ottoman and Modern Greek Studies at the University of Birmingham, and those with similar research interests.

For a full list of titles in this series, please visit www.routledge.com/series/BBOS

\section{Dreams and Lives in Ottoman Istanbul}

A Seventeenth-Century Biographer's Perspective Aslı Niyazioğlu

Byzantium and the Emergence of Muslim-Turkish Anatolia, ca. 1040-1130 Alexander Daniel Beihammer

Cyprus Between Late Antiquity and the Early Middle Ages (ca. 600-800) An Island in Transition

Luca Zavagno

A Tenth-Century Byzantine Military Manual: The Sylloge Tacticorum Translated by Georgios Chatzelis and Jonathan Harris

\section{Writing about Byzantium}

The History of Niketas Choniates

Theresa Urbainczyk

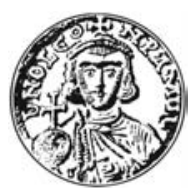

Centre for Byzantine, Ottoman and Modern Greek Studies University of Birmingham 


\section{Writing About Byzantium \\ The History of Niketas Choniates}

\section{Theresa Urbainczyk}


First published 2018

by Routledge

2 Park Square, Milton Park, Abingdon, Oxon OX14 4RN

and by Routledge

711 Third Avenue, New York, NY 10017

Routledge is an imprint of the Taylor \& Francis Group, an informa business

(C) 2018 Theresa Urbainczyk

The right of Theresa Urbainczyk to be identified as author of this work has been asserted by her in accordance with sections 77 and 78 of the Copyright, Designs and Patents Act 1988.

All rights reserved. No part of this book may be reprinted or reproduced or utilised in any form or by any electronic, mechanical, or other means, now known or hereafter invented, including photocopying and recording, or in any information storage or retrieval system, without permission in writing from the publishers.

Trademark notice: Product or corporate names may be trademarks or registered trademarks, and are used only for identification and explanation without intent to infringe.

British Library Cataloguing-in-Publication Data A catalogue record for this book is available from the British Library

Library of Congress Cataloging-in-Publication Data

A catalog record for this book has been requested

ISBN: 978-1-138-73868-3 (hbk)

ISBN: 978-1-315-18461-6 (ebk)

Typeset in Times New Roman

by Apex CoVantage, LLC

Birmingham Byzantine and Ottoman Studies Volume 23 
For Ian Naylor 
$\because$ Taylor \& Francis

Taylor \& Francis Group

http://taylorandfrancis.com 


\section{Contents}

Acknowledgements $\quad$ ix

1 The puzzle of the History of Niketas Choniates 1

2 'A history for workers and women': statements of intent in the preface

3 The world of Byzantine women 31

4 Hellenism and classicism in the History 59

5 The influence of the Old Testament 81

6 Niketas on the emperors 91

7 Conclusion 115

Appendix 1: Addresses to the reader 117

Appendix 2: Niketas'flawless heroes 133

Index 145 
$\because$ Taylor \& Francis

Taylor \& Francis Group

http://taylorandfrancis.com 


\section{Acknowledgements}

I would like to thank University College Dublin for employment and for allowing me to take sabbatical leave. In the course of writing this I took leave in Athens and Kendal, and the time was invaluable for starting this project and for completing it. My interest in Niketas began a long time ago when I was an MA student in Byzantine Studies at the University of Birmingham, and many people have educated me along the way. Perhaps my largest debt in this regard is to the late Professor Bryer, who was always my model for how academics should welcome and nurture their students. It has often been observed that one learns most from teaching, and this has certainly been the case for me, so I must thank UCD students for educating me. I am indebted to the anonymous reader from Routledge for their comments and corrections, and to Michael Greenwood for his patience and encouragement. I would also like to thank belatedly for all their support and help Robert, Susan, John, Emily and Rebecca Bradshaw, Mary Franklin Brown, John Cowley, Michael Hardwick, Tom Loughlin, Sue O'Sullivan, Nigel Rider, all my colleagues in the UCD School of Classics, Tony Urbainczyk and Anna Wilson. This book is dedicated to Ian Naylor, who I hope will never read it, but who enabled me to finish it. 
$\because$ Taylor \& Francis

Taylor \& Francis Group

http://taylorandfrancis.com 


\section{The puzzle of the History of Niketas Choniates}

Niketas Choniates is one of the most important Byzantine historians and yet, relatively speaking, he has not received the attention he deserves. He wrote about one of the most exciting, if tragic, periods of medieval history in an ornate and elevated style. One might expect him to be better studied simply because he described the effects on the Byzantine Empire of the Fourth Crusade. His narrative however is not only worth studying because of its significance to an important period of western medieval history. From the Byzantine perspective, 1204 was a catastrophe, and here we have an eyewitness account of the fall of the city. In 1204 Constantinople, the head of the Byzantine Empire, was captured by the troops of the Fourth Crusade whose aim was supposed to be the liberation of Jerusalem. ${ }^{1}$ Constantinople had never been taken by any enemy in the nine centuries of its position as imperial city. ${ }^{2}$ Niketas describes the period before, during and after this calamitous event. ${ }^{3}$

As Constantinople neared its end, Niketas extended his criticism to everyone for their role in its downfall, everyone who lived there, not so much the Crusaders, who are portrayed as barbarians but little more could be expected from them. ${ }^{4}$ They took advantage of the fatal and obvious weakness of the Byzantines. ${ }^{5}$ Niketas' focus, perhaps as Thucydides' main subject is the Athenians in his history, is on the Byzantines or rather Romans, as he calls the inhabitants of the Byzantine Empire. ${ }^{6}$ Both Thucydides and Niketas were patriots writing about the mistakes of their fellow citizens and trying to understand why the disaster happened. ${ }^{7}$ Towards the end Niketas has a striking aside. The last emperor before the fall of the city was Alexios Doukas, and of him Niketas says:

Inasmuch as the worst elements prevail among the Constantinopolitans (for truth is dearer to me than my compatriots), Doukas grew stronger and increased in power.

$(564 ; \text { my emphasis })^{8}$ 


\section{The puzzle of the History}

And the Greek makes clear what the English leaves ambivalent, which is

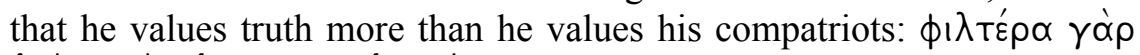

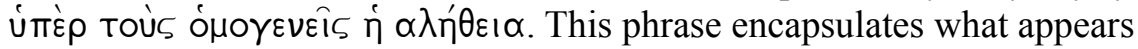
to have driven Niketas to write his history. He wanted above all to write the truth as he saw it, even though it meant criticizing his own people. ${ }^{9}$

Most readers would agree that Niketas wrote his history to understand the calamity that had struck his city, and most would agree that he laid the blame generally with the rulers and yet there is much that is puzzling about the work. ${ }^{10}$ Anthony Kaldellis started his article on Niketas titled 'Paradox, Reversal and the Meaning of History' with the following paragraph:

Those who wish to study Niketas Choniates as both a historian and a sophisticated writer face a formidable challenge. The mountain to be climbed is tall and steep and there are no 'royal highways' to the top. It is possible that no one has been there before. If the view promises to be spectacular, the ascent is sure to be treacherous. Niketas left no directions, despite the fact that he created something new, something that he knew would confound the expectations of even the most seasoned climbers. Any place where we might pause may collapse beneath our feet; there are pits and deep caverns everywhere; or else, his grottos may be so charming that, like Siren songs, they entice us to linger and give up the ascent. Likewise, we cannot afford to be dizzied by the spiraling chasms of irony and paradox. We can take little for granted here. Where is the solid ground in Niketas Choniates' History? ${ }^{11}$

And he carries on:

\section{I have no answer to that question. ${ }^{12}$}

The rest of the article illustrates some of the difficulties of the text, such as the preface and the way that Andronikos is portrayed in the most negative manner, and yet when he is torn apart by the Constantinopolitan populace, Niketas turns against 'the stupid and most ignorant inhabitants of Constantinople'. ${ }^{13}$ As Kaldellis points out, it is very difficult to see exactly what Niketas himself thought as one judgement may immediately be undercut by the following remark. ${ }^{14}$ He may describe an emperor in the blackest terms and then go on to praise him for extraordinary benefits he brought the empire. He narrated how Manuel framed one of his faithful subjects because he was envious of his abilities, and then says 'A glorious deed was now performed by the emperor' without appearing to be ironic since he describes how the cities of the East flourished under his rule (150). Or later, having described the random cruelty 
of Andronikos, he comments 'yet he did participate in many virtuous actions' (323-325). What follows is a search for some solid ground in Niketas' History.

The work is very sophisticated, using recondite vocabulary, and it is also difficult to read and to understand. It appears to be a classicizing history ${ }^{15}$ and yet the author most frequently cited is Homer, which to classicists seems odd, since this is a historical work. ${ }^{16}$ Another complication is that there were different versions of his history circulating. ${ }^{17}$ It appears that at first there was a history which would have been acceptable to the ruling emperor, but then once Constantinople fell, Niketas felt free to write as he wished, and the result was very different. ${ }^{18}$ One might attribute the apparently contradictory judgements as being the result of careless or rapid editing. ${ }^{19}$ But complexity seems to be part of the text. ${ }^{20}$ The preface itself is one of the clearest examples of Niketas' lack of clarity and will be discussed in Chapter 2.

\section{Niketas' life}

The name Choniates comes from the place Chonai, modern Honaz/ Khonaz - Colossae in the classical period, in Phrygia - southwestern Turkey, which is where he was from. ${ }^{21} \mathrm{He}$ also had a prominent brother, Michael Choniates, bishop of Athens (1182-1204), who wrote letters and a monodia or lament when Niketas died. ${ }^{22}$ None of Niketas' letters to him has survived and only one of Michael's to Niketas remains, but there are bits and pieces of information in others. ${ }^{23}$ Michael relates that the boys were educated in Constantinople as their parents were rich enough to send their sons to the capital for their education, although they are thought not to be from the aristocracy. ${ }^{24}$ Niketas was born about 1155 and had a career as a bureaucrat, first as a sort of tax officer, then as imperial undersecretary; then he studied law, and afterward was appointed imperial secretary; by 1188-1189 was head of the public treasury. Although we know of his titles thanks to his brother Michael, it is not entirely clear what these positions entailed. ${ }^{25}$

The high point of his career was his appointment of grand logothete in 1195 , but he was removed from this pinnacle when the emperor changed, just two months before the fall of Constantinople in $1204 .{ }^{26}$ Niketas tells the reader that he lost his job (565) and then describes how then with the sack of the city he also lost his home and property (587-595). He and his family went into exile first to Selymbria and then to Nicaea, after briefly returning to Constantinople and seeing the destruction of the artistic masterpieces by the barbarian army (635-636). From Michael's funeral address we learn that Niketas died about 30 years after Michael became 


\section{The puzzle of the History}

bishop of Athens in 1182, so thus it must have been about 1215 or 1216 when he would have been 60 or $61 .^{27}$

\section{His history}

His history starts with the death of Alexios Komnenos in 1118 (Alexios I) and ends with events of 1207, so it carries on a little after the taking of the city. In the organization of his history he does not follow the classical Greek historians, but one might say he models his work on a writer like Tacitus, in that his history goes from emperor to emperor. ${ }^{28}$ It could be argued that history-writing is dependent on whatever its focus is. ${ }^{29}$ Thucydides, because he was writing about city-states, was able to keep his work about governments rather than individuals. The Roman historians in the imperial period tended much more towards biography because the power of the emperor was so great. ${ }^{30}$ The History was largely about Niketas' own lifetime and where he goes further back, he acknowledges this. He says:

Since I was not an eyewitness of that which I have recorded [that is John's reign] I could not describe these events extensively but have set down what I heard from those contemporaries who personally knew the emperor and who escorted him on his campaigns against the enemy and accompanied him into battle.

What follows is not an investigation into his sources. That is not to say this is not an important question, but my main aim here is to look at what Niketas does with his material, what impression he is trying to give the reader, and to examine the views he reveals in the work. ${ }^{32}$ Because it seemed to me that the work as a whole was intriguing, I wanted to examine it further. There is an excellent book recently published on Niketas by Alicia Simpson, which has already been referred to several times in this chapter. ${ }^{33}$ Without this pioneering work, this book would have been very different. She has not only given the basic background to his work and describes the nature of his text, but has done invaluable research on the different versions of the history that the manuscript tradition bears witness to. This work in no way supersedes hers, but instead builds on the huge learning displayed in her book, to suggest a way of understanding Niketas that helps the reader approach this complex text. As will become apparent, there are many difficulties with this history. Andrea Catanzaro has recently produced an article, one might say trying to impose some taxis on the text. ${ }^{34}$ What follows is the result of my own attempts to find a key to this challenging text. I came to this text as a classicist, and I am sure Byzantinists 
will find much that is lacking in what follows. Nevertheless, it seemed to me that it would be fruitful for someone with a knowledge of the historiography of antiquity to examine this most learned and allusive history. For me, what soon became striking as I became better acquainted with the text was that, although superficially it owes much to classical learning, its more important model was the Old Testament, as one indeed might expect. One might also suggest that the many apparent paradoxes or puzzles in Niketas' work have a model too in the Bible itself. ${ }^{35}$ Harry J. Magoulias published a translation in 1984 titled O City of Byzantium, Annals of Niketas Choniates. ${ }^{36}$ This book is often singled out for criticism for mistakes in translation, however Magoulias did the scholarly community a service in making the text accessible to a much wider readership. ${ }^{37}$ Plus it must be noted again that the text is very difficult to understand. Consequently the German translation by Franz Grabler and the Italian one by Anna Pontani have been consulted also. ${ }^{38}$ However, unless stated otherwise, quotations will be based on Magoulias' and the references to Niketas' text from the van Dieten edition, as is conventional. ${ }^{39}$ Magoulias, using van Dieten's apparatus, also provided a helpful introduction and notes indicating the echoes in the text. I have sometimes used these notes as will become apparent, but the numbering for the Psalms and references for the Bible I have taken from the New Revised Standard Version. ${ }^{40}$

The following chapter will look at the preface, which is not long but which contains several puzzles. The examination of these few pages not only is a study of what Niketas thought he was doing when he wrote his history, but it also gives a good indication of what to expect in the body of the work. Some comparison with Anna Komnene is made, and it is suggested that Niketas had her work in mind when he wrote his own. Anna Komnene can be seen as an important figure for Niketas, not only because of her history but because of her ambitions which we learn about in the first few pages of his history, where he gives a very negative portrait of this famous figure. In Chapter 3, his descriptions of female characters are looked at more closely. They can be seen as a key to his judgements about the men in their lives, so that the powerful but destructive Anna and her mother Irene can be seen to reflect badly on Alexios I Komnenos. Similarly other women that appear in his pages give an indication of his judgement of the men in their lives, usually their husbands.

Chapter 4 looks at the classical allusions in Niketas' work, which has often simply been described as a classicizing work. On closer inspection however, this seems to be a distracting description. Niketas was not concerned to allude to the great historians of antiquity. His classical learning could be seen more as the grammar of the high register of his language, rather than a tool he consciously deployed. The classical allusions decorate 


\section{The puzzle of the History}

the work, and the vocabulary owes much to the vastness of his education, but the main text that influenced the history is the Old Testament.

The next chapter then continues the discussion from the previous one, and demonstrates the debt owed to the Old Testament and considers why Niketas turned to that rather than the New Testament. Niketas is often consulted because of the information he provides on the reigns of emperors in the hundred years leading to the fall of Constantinople. Chapter 6 considers what difference having the Old Testament as a model makes to the way we read what Niketas has to say about the individuals, and how he chooses to criticize or praise them.

\section{Notes}

1 For a survey of the crusades, see Harris 2014:155-193, Brand 1968:232-269 is now old but remains a clear narrative.

2 Simpson 2013:1-2 sets the scene clearly.

3 'The twelfth and early thirteenth centuries in Byzantine history are largely known to us through the History of Niketas Choniates' (Simpson 2013:1).

As a historian Niketas is a major figure, embittered and disillusioned by the tragedy of his times, he wrote a lengthy and sophisticated narrative that is the single most important source for Byzantine history in the twelfth and early thirteenth centuries. It is also the principal Greek eyewitness account of the capture of Constantinople by the armies of the Fourth Crusade in 1204. (Simpson 2009:14)

4 Simpson 2013 appendix 3 looks at Niketas' depiction of some of the Byzantines' enemies.

5 'The historian sought to understand the tragedy of Byzantium primarily in terms of the excesses and corruption of Byzantine society and its rulers, and viewed the conquest of Constantinople as an act of divine retribution' (Simpson 2009:22).

6 See Page 2008 passim on the way the Byzantines described themselves, and chapter 3 in particular on Niketas' terminology.

7 See Rechenauer and Pothou 2011 for thoughts on the way Thucydides wrote his history.

8 This passage is discussed in Chapter 2. Page numbers for Niketas' text are from van Dieten's edition.

9 See Chapter 2 for a discussion of the echoes in this phrase.

10 Simpson 2013:291 says, 'He [Niketas] assigns much of the blame to imperial misrule, especially during the reigns of Isaac and Alexios III, but significantly he does not overlook collective responsibility.' Simpson 2009:27:

The praise and censure of leading individuals, the dominant role assigned to divine providence, the instability of fortune and the sudden reversals in the lives of men, the examples of virtue and vice cited for ethical instruction and the continual moralizing of the historian all point the ancient principles of public utility, moral instruction and didactic function of historical narratives. It is precisely these principles that define Niketas' historical outlook and give meaning to the events narrated in his History.

11 Kaldellis 2009:75.

12 Kaldellis 2009:75.

13 Kaldellis 2009:96. The passage of Niketas is pp. 349-350 in the van Dieten edition. The preface and the depiction of Andronikos will be discussed in later chapters. 
14 Kaldellis 2009:96: 'Niketas is manipulating reversal and paradox to have an effect on his readers, but what effect?'

15 Simpson 2013:131-132:

The work has been traditionally grouped within the category of classicizing histories on the basis of format, language, and content. The choice of contemporary and near contemporary history, the format of imperial biographies along with the complex rhetorical language, the use of rare and archaizing vocabulary and the multitude of citations and allusions drawn from ancient sources would certainly indicate this to be the case ... in addition to the classicizing characteristics ascribed to the History we should also include the pervasive presence of 'trivial' contextual elements usually associated with chronicles.

16 Ljubarskij 2000:171, Saxey 2009, Efthymiades 2009b, Simpson 2013:274-279.

17 Simpson 2013:68-127, Simpson 2006.

18 Simpson 2013:76-77.

19 See the discussion in Simpson 2013:77-80 for further complications.

20 As emphasized in Kaldellis 2009. See also Efthymiades 2009a and 2009a.

21 Niketas tells us this himself, 178 and 638. Page 2008:73-76 for a brief overview of Niketas' life and career. See Simpson 2013:11-23 for what is known of his life.

22 Niketas is proud of his brother and says so, 605-606.

23 See Magoulias 1984:ix-xii.

24 See Simpson 2013:13.

25 See Simpson 2013:15-22 on his career.

26 See Simpson 2013:20 n.59 on the different versions of the exact title.

27 Magoulias 1984:xvi.

28 Simpson 2013:129-135 discusses the genre of the work.

29 Matthews 2007 on the biographical nature of imperial history.

30 Jerome (Commentary on Zachariah 3.14) described Tacitus' Annals and the Histories as 'Lives of the Caesars in thirty books', as Matthews notes, 2007:291.

31 See Simpson 2013:214-250 on the sources for the history.

32 It does seem, for instance, that he used the history of Kinnamos but the result is very different from Kinnamos' account. See, for instance, the different views of John Axouch: Niketas goes out of his way to praise Axouch: 'he excelled in generalship, was brave in hand-to-hand combat, and endowed with qualities of great leadership' (82). Whereas Kinnamos' narrative gives a far less favourable view of this individual, e.g. III.6. In Niketas' book 4 of Manuel's reign, there is a lengthy account of some adventures of Andronikos, whom we had met earlier, not having been ransomed by Manuel because he was too busy establishing his succession. Andronikos is not described favourably, but neither is much sympathy shown for Manuel by Niketas. Andronikos sought refuge with Saltuq, a Turkish emir, whose lands included Koloneia and Chaldia in the Black Sea region. The paragraph ends saying that Andronikos was skillful in evading Manuel's attempts to arrest him. The next paragraph is about how powerful men fear their excellent subjects and seek to destroy them as potential threats. It's a very striking passage, written with vivid and evocative language and there is no ambiguity in it (143). It would seem that this paragraph coming immediately after describing how Manuel wanted to arrest Andronikos was about him but in fact it would seem that it is introducing a new story; that is Manuel's persecution of the innocent Alexios Axouch. It might seem that Alexios can hardly be described as a Turk although he was John Axouch's son, who was mentioned at the start of this chapter. See Angold 1997:190 who suggests that the Axouch family formed a pro-Seljuk faction at court, opposing a pro-western clique. See also Brand 1989 who discusses these two conflicting accounts, and Maisano 1994. Alexios was very well connected, being married to Maria, daughter of Manuel's older brother Alexios (who had died in 1142) and protostrator. He was John Axouch's oldest son and a man very much trusted by the emperor (97-98). The 


\section{The puzzle of the History}

way Niketas presents the story, Alexios is completely innocent and Manuel is a monster. However Kinnamos has a different account, accusing Axouch of being a friend of Kilij Arslan and discussing usurpation with him (book VI, 266). Axouch seems to have been extremely indiscrete about his affiliations because Kinnamos tells us that he had one of his houses painted with murals, not of ancient Greek feats, nor of the emperor's deeds, but commemorating the sultan's military achievements. Confusingly (if there were pro-Seljuq factions versus pro-western factions) Axouch also, according to Kinnamos consulted a Latin magician and wizard (267). One might say that Niketas clearly wants to portray Axouch positively, and there is nothing in Axouch's behaviour in his account that could attract any criticism.

33 Simpson 2013, as well as several excellent articles which are referred to in the course of this book.

34 Catanzaro 2012. He starts off saying

Although we cannot consider the Byzantine historian Niketas Choniates a political thinker in the strict sense of the word, it is possible to find in his Chronike Dieghesis some significant elements of political thought concerning the situation in the Byzantine Empire in the XIIth century. One of the most important among them is the theme of $\propto \sigma \phi \alpha^{\prime} \lambda \varepsilon 1 \propto$ which represents, in my opinion, a peculiar characteristic of Niketas' political thought. (221-222)

Catanzaro's discussion does throw light on certain aspects of features of the narrative.

35 See for instance Basinger 1987.

36 Magoulias 1984.

37 See for instance Simpson's comments, 2013:3 and 2009:15.

38 Kazhdan, Maisano and Pontani 1994, van Dieten and Pontani 1999, Pontani 2014 and Grabler 1958a, 1958b, 1958c. This last though is based on an earlier edition by Immanuel Bekker from 1835.

39 Van Dieten 1975.

40 Published by the Society for Promoting Christian Knowledge, London. Sometimes these references are not the same as in Magoulias' translation.

\section{Bibliography}

Angold, Michael, 1997, The Byzantine Empire, Pearson, London.

Basinger, David, 1987, 'Biblical Paradox: Does Revelation Challenge Logic?' Journal of the Evangelical Theological Society 30/2, pp. 205-213.

Brand, Charles M., 1968, Byzantium Confronts the West 1180-1204, Gregg Revivals, Aldershot.

Brand, Charles M., 1989, 'The Turkish Element in Byzantium, Eleventh-Twelfth Centuries' Dumbarton Oaks Papers 43, pp. 1-25.

Catanzaro, Andrea, 2012, 'The Political Problem of Internal A $\triangle \Phi A \wedge E I A$ in Niketas Choniates' Chronike Dieghesis: A Contributing Factor to the Constantinople's Fall in 1204' Byzantina Symmeikta 22, pp. 221-242.

Efthymiades, Stephanos, 2009a, 'Niketas Choniates: The Writer' in Simpson and Efthymiades, ed. 2009, pp. 35-58.

Efthymiades, Stephanos, 2009b, 'Greek and Biblical Exempla in the Service of an Artful Writer' in Simpson and Efthymiades, ed. 2009, pp. 101-119.

Gouma-Peterson, Thalia, 2000a, 'Gender and Power: Passages to the Maternal in Anna Komnene's Alexiad' in Gouma-Peterson, ed. 2000, pp. 107-124.

Gouma-Peterson, Thalia, ed., 2000b, Anna Komnene and Her Times, Garland, New York. 
Grabler, Franz, 1958a, Die Krone der Komnenen. Die Regierungszeit der Kaiser Joannes und Manuel Komnenos (1118-1180) aus dem Geschichtswerk des Niketas Choniates. Byzantinische Geschichtsschreiber, Vol. 7, Verlag Styria, Graz.

Grabler, Franz, 1958b, Abenteurer auf dem Kaiserthron. Die Regierungszeit der Kaiser Alexios II, Andronikos und Isaak Angelos (1180-1195) aus dem Geschichtswerk des Niketas Choniates. Byzantinische Geschichtsschreiber, Vol. 8, Verlag Styria, Graz.

Grabler, Franz, 1958c, Die Kreuzfahrer erobern Konstantinopel. Die Regierungszeit der Kaiser Alexios Angelos, Isaak Angelos uns Alexios Dukas, die Schicksale der Stadt nach der Einnahme sowie das "Buch von den Bildsäulen" (1195-1206) aus dem Geschichtswerk des Niketas Choniates. Byzantinische Geschichtsschreiber, Vol. 9 Verlag Styria, Graz.

Harris, Jonathan, 2014, Byzantium and the Crusades, 2nd edition, Bloomsbury, London.

Kaldellis, Anthony, 2007, Hellenism in Byzantium: The Transformation of Greek Identity and the Reception of the Classical Tradition, Cambridge University Press, Cambridge.

Kaldellis, Anthony, 2009, 'Niketas Choniates: Paradox, Reversal and the Meaning of History' in Simpson and Efthymiades, ed. 2009, pp. 75-99.

Kazhdan, A., Maisano, R., and Pontani, A., ed., 1994, Niceta Coniata. Grandezza e catastrofe di Bisanzio, vol. I, XIV-XV, Fondazione Lorenzo Valla, Milan.

Kinnamos, John, 1976, Deeds of John and Manuel Comnenus, translated by Charles M. Brand, Columbia University Press, New York.

Ljubarskij, Jakov, 2000, 'Why is the Alexiad a Masterpiece of Byzantine Literature?' in Gouma-Peterson, 2000b, pp. 169-185.

Magoulias, Harry, 1984, O City of Byzantium, Annals of Niketas Choniates, Wayne State University Press, Detroit.

Maisano, Riccardo, 1994, 'Tipologia delle fonti di Niceta Coniata (Libri I-VIII)' in Storia poesia e pensiero nel mondo antico. Studi in onore di Marcello Gigante, Dipartimento di archeologica, filologia classica e loro tradizioni, Napoli, pp. 391-405.

Matthews, John, 2007, 'The Emperor and His Historians' in A Companion to Greek and Roman Historiography, edited by John Marincola, Blackwell, Oxford, pp. 290-304.

Page, Gill, 2008, Being Byzantine: Greek Identity Before the Ottomans, Cambridge University Press, Cambridge.

Pontani, Anna, 2014, Niceta Coniata: Grandezza e catastrophe di Bisanzio, vol. 3, XVXIX, Fondazione Lorenzo Valla, Milan.

Pontani, Anna and van Dieten, Jan-Louis, ed., 1999, Niceta Coniata. Grandezza e catastrofe di Bisanzio, vol. II, IX-XIV, Fondazione Lorenzo Valla, Milan.

Rapp, Claudia, 2010, 'Old Testament Models for Emperors in Early Byzantium' in Magdalino and Nelson, ed. 2010, pp. 175-197.

Rechenauer, Georg and Pothou, Vassiliki, ed., 2011, Thucydides: A Violent Teacher? History and Its Representations, Vandenhoeck and Ruprecht, Göttingen.

Saxey, Roderick, 2009, 'The Homeric Metamorphosis of Andronikos II Komnenos' in Efthymiades and Simpson, ed. 2009, pp. 121-143.

Scott, Roger, 1981, 'The Classical Tradition in Byzantine Historiography' in Mullett and Scott, ed. 1981, pp. 61-74.

Simpson, Alicia, 2006, 'Before and After 1204: The Versions of Niketas Choniates' Historia' Dumbarton Oaks Papers 60, pp. 189-221.

Simpson, Alicia, 2009, 'Introduction: Niketas Choniates: The Historian' in Simpson and Efthymiades, ed. 2009, pp. 13-34.

Simpson, Alicia, 2013, Niketas Choniates: A Historiographical Study, Cambridge University Press, Cambridge. 


\section{The puzzle of the History}

Simpson, Alicia and Efthymiades, Stephanos, ed., 2009, Niketas Choniates: A Historian and a Writer, Pomme d'Or, Geneva.

Ustinova, Yulia, 1999, The Supreme Gods of the Bosporan Kingdom: Celestial Aphrodite and the Most High God, Brill, Leiden.

van Dieten, Jan-Louis, 1975, Nicetae Choniatae historia (Corpus Fontium Historiae Byzantinae), vol. XI, 2 vols., de Gruyter, Berlin.

van Dieten, Jan-Louis and Pontani, Anna, 1999, Niceta Coniata: Grandezza e catastrophe di Bisanzio (Narrazione cronologica), vol. 2, Fondazione Lorenzo Valla Milan. 


\section{The puzzle of the History of Niketas Choniates}

Angold, Michael , 1997, The Byzantine Empire, Pearson, London.

Basinger, David , 1987, 'Biblical Paradox: Does Revelation Challenge Logic?' Journal of the

Evangelical Theological Society 30/2, pp. 205-213.

Brand, Charles M. , 1968, Byzantium Confronts the West 1180-1204, Gregg Revivals,

Aldershot.

Brand, Charles M. , 1989, 'The Turkish Element in Byzantium, Eleventh-Twelfth Centuries'

Dumbarton Oaks Papers 43, pp. 1-25.

Catanzaro, Andrea, 2012, 'The Political Problem of Internal A $\Phi$ A $А E I A$ in Niketas Choniates'

Chronike Dieghesis: A Contributing Factor to the Constantinople's Fall in 1204' Byzantina

Symmeikta 22, pp. 221-242.

Efthymiades, Stephanos , 2009a, 'Niketas Choniates: The Writer' in Simpson and Efthymiades , ed. 2009, pp. 35-58.

Efthymiades, Stephanos , 2009b, 'Greek and Biblical Exempla in the Service of an Artful Writer' in Simpson and Efthymiades, ed. 2009, pp. 101-119.

Gouma-Peterson, Thalia , 2000a, 'Gender and Power: Passages to the Maternal in Anna Komnene's Alexiad' in Gouma-Peterson, ed. 2000, pp. 107-124.

Gouma-Peterson, Thalia, ed., 2000b, Anna Komnene and Her Times, Garland, New York.

Grabler, Franz , 1958a, Die Krone der Komnenen. Die Regierungszeit der Kaiser Joannes und

Manuel Komnenos (1118-1180) aus dem Geschichtswerk des Niketas Choniates.

Byzantinische Geschichtsschreiber, Vol. 7, Verlag Styria, Graz.

Grabler, Franz , 1958b, Abenteurer auf dem Kaiserthron. Die Regierungszeit der Kaiser Alexios

II, Andronikos und Isaak Angelos (1180-1195) aus dem Geschichtswerk des Niketas

Choniates. Byzantinische Geschichtsschreiber, Vol. 8, Verlag Styria, Graz.

Grabler, Franz , 1958c, Die Kreuzfahrer erobern Konstantinopel. Die Regierungszeit der Kaiser

Alexios Angelos, Isaak Angelos uns Alexios Dukas, die Schicksale der Stadt nach der

Einnahme sowie das "Buch von den Bildsäulen" (1195-1206) aus dem Geschichtswerk des

Niketas Choniates. Byzantinische Geschichtsschreiber, Vol. 9 Verlag Styria, Graz.

Harris, Jonathan , 2014, Byzantium and the Crusades, 2nd edition, Bloomsbury, London.

Kaldellis, Anthony , 2007, Hellenism in Byzantium: The Transformation of Greek Identity and the

Reception of the Classical Tradition, Cambridge University Press, Cambridge.

Kaldellis, Anthony , 2009, 'Niketas Choniates: Paradox, Reversal and the Meaning of History' in Simpson and Efthymiades, ed. 2009, pp. 75-99.

Kazhdan, A. , Maisano, R. , and Pontani, A. , ed., 1994, Niceta Coniata. Grandezza e catastrofe di Bisanzio, vol. I, XIV-XXV, Fondazione Lorenzo Valla, Milan.

Kinnamos, John , 1976, Deeds of John and Manuel Comnenus, translated by Charles M. Brand , Columbia University Press, New York.

Ljubarskij, Jakov , 2000, 'Why is the Alexiad a Masterpiece of Byzantine Literature?' in GoumaPeterson, 2000b, pp. 169-185.

Magoulias, Harry, 1984, O City of Byzantium, Annals of Niketas Choniates, Wayne State University Press, Detroit.

Maisano, Riccardo , 1994, 'Tipologia delle fonti di Niceta Coniata (Libri I-VIII)' in Storia poesia e pensiero nel mondo antico. Studi in onore di Marcello Gigante, Dipartimento di archeologica, filologia classica e loro tradizioni, Napoli, pp. 391-405.

Matthews, John , 2007, 'The Emperor and His Historians' in A Companion to Greek and Roman Historiography, edited by John Marincola, Blackwell, Oxford, pp. 290-304.

Page, Gill , 2008, Being Byzantine: Greek Identity Before the Ottomans, Cambridge University Press, Cambridge.

Pontani, Anna, 2014, Niceta Coniata: Grandezza e catastrophe di Bisanzio, vol. 3, XV-XIX, Fondazione Lorenzo Valla, Milan.

Pontani, Anna and van Dieten, Jan-Louis , ed., 1999, Niceta Coniata. Grandezza e catastrofe di Bisanzio, vol. II, IX-XIV, Fondazione Lorenzo Valla, Milan.

Rapp, Claudia , 2010, 'Old Testament Models for Emperors in Early Byzantium' in Magdalino and Nelson, ed. 2010, pp. 175-197.

Rechenauer, Georg and Pothou, Vassiliki , ed., 2011, Thucydides: A Violent Teacher? History and Its Representations, Vandenhoeck and Ruprecht, Göttingen. 
Saxey, Roderick, 2009, 'The Homeric Metamorphosis of Andronikos II Komnenos' in Efthymiades and Simpson, ed. 2009, pp. 121-143.

Scott, Roger , 1981, 'The Classical Tradition in Byzantine Historiography' in Mullett and Scott , ed. 1981, pp. 61-74.

Simpson, Alicia , 2006, 'Before and After 1204: The Versions of Niketas Choniates' Historia' Dumbarton Oaks Papers 60, pp. 189-221.

Simpson, Alicia , 2009, 'Introduction: Niketas Choniates: The Historian' in Simpson and Efthymiades, ed. 2009, pp. 13-34.

Simpson, Alicia , 2013, Niketas Choniates: A Historiographical Study, Cambridge University Press, Cambridge.

Simpson, Alicia and Efthymiades, Stephanos, ed., 2009, Niketas Choniates: A Historian and a Writer, Pomme d'Or, Geneva .

Ustinova, Yulia, 1999, The Supreme Gods of the Bosporan Kingdom: Celestial Aphrodite and the Most High God, Brill, Leiden.

van Dieten, Jan-Louis , 1975, Nicetae Choniatae historia (Corpus Fontium Historiae Byzantinae), vol. XI, 2 vols., de Gruyter, Berlin.

van Dieten, Jan-Louis and Pontani, Anna , 1999, Niceta Coniata: Grandezza e catastrophe di Bisanzio (Narrazione cronologica), vol. 2, Fondazione Lorenzo Valla Milan.

\section{'A history for workers and women'}

Cain, Andrew , 2016, The Greek Historia Monachorum in Aegypto: Monastic Hagiography in the Late Fourth Century, Oxford University Press, Oxford.

Gamble, Harry , 1995, Books and Readers in the Early Church, Yale University Press, New Haven.

Gouma-Peterson, Thalia, ed., 2000, Anna Komnene and Her Times, Garland, New York. Grigoriadis, Iordanis , 1998, 'A Study of the Pr ooimion of Zonaras' Chronicle in Relation to other 12th Century Prooimia', Byzantinische Zeitschrift 91, pp. 327-344.

Hill, Barbara , 2000, 'Actions Speak Louder Than Words: Anna Komnene's Attempted Usurpation' in Gouma-Peterson, ed. 2000, pp. 45-62.

Kaldellis, Anthony , 2007, Hellenism in Byzantium: The Transformation of Greek Identity and the Reception of the Classical Tradition, Cambridge University Press, Cambridge.

Kaldellis, Anthony , 2009, 'Niketas Choniates: Paradox, Reversal and the Meaning of History' in Simpson and Efthymiades, ed. 2009, pp. 75-99.

Laiou, A. , 2000, 'Why Anna Komnene?' in Gouma-Peterson, ed. 2000, pp. 1-14.

Louden, Bruce, 2006, The Iliad: Structure, Myth and Meaning, Johns Hopkins University Press, Baltimore.

Ljubarskij, Jakov , 2000, 'Why is the Alexiad a Masterpiece of Byzantine Literature?' in GoumaPeterson , 2000b, pp. 169-185.

MacMullen, Ramsay, 1966, 'A Note on Sermo Humilis' Journal of Theological Studies 17, pp. 108-112.

Macrides, Ruth , 2000, 'The Pen and the Sword: Who Wr ote the Alexiad?' in Gouma-Peterson , ed. 2000, pp. 63-81.

Macrides, Ruth and Magdalino, Paul , 1992, 'The Fourth Kingdom and the Rhetoric of Hellenism' in Magdalino , ed. 1992, pp. 117-156.

Magdalino, Paul , 2000, 'The Pen of the Aunt: Echoes of the Mid-Twelfth Century in the Alexiad' in Gouma-Peterson , ed. 2000, pp. 15-43.

Magdalino, Paul , 2009, 'Prophecy and Divination in the History' in Simpson and Efthymiades , ed. 2009, pp. 59-74.

Magoulias, Harry, 1984, O City of Byzantium, Annals of Niketas Choniates, Wayne State University Press, Detroit.

Maisano, Riccardo , 1994, 'Variante d'autore in Niceta Coniata?' in Problemi di ecdotica ed esegesi di testi byzantini e grecomedievali, edited by R. Romano , Diparti mento di archeologica , filologia classica e loro tradizioni, Napoli , pp. 63-80. 
Mullett, Margaret , 2013, 'How to Criticize the laudandus' in Power and Subversion in Byzantium: Papers From the Forty-third Spring Symposium of Byzantine Studies, Birmi ngham, March 2010. Publications of the Society for the Promotion of Byzantine Studies, 17, edited by Dimiter Angelov and Michael Saxby , Ashgate, Farnham , pp. 247-262.

Neville, Leonora , 2012, Heroes and Romans in Twelfth-Century Byzantium, Cambridge University Press, Cambridge.

Neville, Leonora , 2016, Anna Komnene: The Life and Work of a Medieval Historian, Oxford University Press, Oxford.

Page, Gill , 2008, Being Byzantine: Greek Identity Before the Ottomans, Cambridge University Press, Cambridge.

Polemis, Demetrios , 1968, Doukai: Contribution to Byzantin e Prosopography, Athlone Press, London.

Saxey, Roderick , 2009, 'The Homeric Metamorphosis of Andronikos II Komnen os' in Simpson and Efthymiades, ed. 2009, pp. 121-143.

Scott, Roger , 1981, 'The Classical Tradit ion in Byzantine Historiography' in Mullett and Scott , ed. 1981, pp. 61-74.

Simpson, Alicia , 2006, 'Before and After 1204: The Vers ions of Niketas Choniates' Historia' Dumbarton Oaks Papers 60, pp. 189-221.

Simpson, Alicia , 2009, 'Introduction: Niketas Choniates: The Historian' in Simpson and Efthymiades, ed. 2009, pp. 13-34.

Simpson, Alicia , 2013, Niketas Choniates: A Historiographical Study, Cambridge University Press, Cambridge.

Simpson, Alicia, and Efthymiades, Stephanos, ed., 2009, Niketas Choniates: A Historian and a Writer, Pomme d'Or, Geneva.

Urbainczyk, Theresa , 1997, Socrates of Constantinople: History of Church and State, University of Michigan Press, Ann Arbor.

Urbainczyk, Theresa, 2008, Slave Revolts in Antiquity, Acumen, Durham.

van Dieten , Jan-Louis , 1975, Nicetae Choniatae historia (Corpus Fontium Historiae

Byzantinae), vol. XI, 2 vols. de Gruyter, Berlin.

\section{The world of Byzantine women}

Catanzaro, Andrea , 2012, 'The Political Problem of Internal ASFALEIA in Niketas Choniates' Chronike Dieghesis: A Contributing Fact or to the Constantinople's Fall in 1204' in Byzantina Symmeikta 22, pp. 221-242.

Cooper, Kate , 1992, 'Insinuations of Womanly Influence: An Aspect of the Christianisation of the Roman Aristocracy' Journal of Roman Studies 82, pp. 150-164.

Davis, John , 2009, 'The History Metaphrased: Changing Readership in the Fourteenth Century' in Simpson and Efthymiades, ed. 2009, pp. 145-163.

Efthymiades, Stephanos , 2009a, 'Niketas Choniates: The Writer' in Simpson and Efthymiades ed., 2009, pp. 35-58.

Efthymiades, Stephanos , 2009b, 'Greek and Biblical Exempla in the Service of an Artful Writer' in Simpson and Efthymiades, ed. 2009, pp. 101-119.

Garland, Lynda, 1999, Byzantine Empresses: Women and Power in Byzantium AD 527-1204, Routledge, London.

Gouma-Peterson, Thalia, ed., 2000, Anna Komnene and Her Times, Garland, New York. Hill, Barbara , 2000, 'Actions Speak Louder Than Words: Anna Komnene's Attempted Usurpation' in Gouma-Peterson, ed. 2000, pp. 45-62.

Kaldellis, Anthony , 2007, Hellenism in Byzantium: The Transformation of Greek Identity and the Reception of the Classical Tradition, Cambridge University Press, Cambridge.

Kaldellis, Anthony , 2009, 'Niketas Choniates: Paradox, Reversal and the Meaning of History' in Simpson and Efthymiades ed. 2009, pp. 75-99.

Laiou, A. , 1991, 'The Foreigner and the Stranger in 12th Century Byzantium: Means of Propitiation and Acculturation' in Fremde der Gesellschaft: Historische und socialswissenschaftliche Untersuchungen zur Differenzierung von Normalität and Fremdheit, 
edited by M. T. Fögen, Frankfurt, pp. 71-97, reproduced in Byzantium and the Other: Relations and Exchanges, edited by Cécile Morrisson and Rowan Dorin , 2012, Ashgate, Farnham.

Laiou, A. , 2000, 'Why Anna Komnene?' in Gouma-Peterson, ed. 2000, pp. 1-14.

Ljubarskij, Jakov, 2000, 'Why is the Alexiad a Masterpiece of Byzantine Literature?' in GoumaPeterson, 2000b, pp. 169-185.

Macrides, Ruth , 2000, 'The Pen and the Sword: Who Wrote the Alexiad ?' in Gouma-Peterson , ed. 2000, pp. 63-81.

Macrides, Ruth , 2007, George Akropolites: The History, Oxford University Press, Oxford. Macrides, Ruth, ed., 2010, History as Literature in Byzantium, Ashgate, Farnham.

Magdalino, Paul , 1993, The Empire of Manuel I Komnenos 1143-1180, Cambridge University Press, Cambridge.

Magoulias, Harry, 1984, O City of Byzantium, Annals of Niketas Choniates, Wayne State University Press, Detroit.

Maisano, Riccardo , 1997, 'Memoria letteraria e memoria storica il personaggio di Giovanni Axouch nell'opera di Niceta Coniata' Atti dell'Accademia Pontaniana n.s.XLVI, pp. 155-172. Neville, Leonora , 2012, Heroes and Romans in Twelfth-Century Byzantium, Cambridge University Press, Cambridge.

Neville, Leonora , 2016, Anna Komnene: The Life and Work of a Medieval Historian, Oxford University Press, Oxford.

Papamastorakis, Titos , 2009, 'Interpreting the De Signis of Niketas Choniates' in Efthymiades and Simpson, ed. 2009, pp. 209-223.

Simpson, Alicia , 2006, 'Before and After 1204: The Versions of Niketas Choniates'

Historia'Dumbarton Oaks Papers 60, pp. 189-221.

Simpson, Alicia , 2009, 'Introduction: Niketas Choniates: The Historian' in Simpson and Efthymiades, ed. 2009, pp. 13-34.

Simpson, Alicia , 2013, Niketas Choniates: A Historiographical Study, Cambridge University Press, Cambridge.

Simpson, Alicia and Efthymiades, Stephanos, ed., 2009, Niketas Choniates: A Historian and a Writer, Pomme d'Or, Geneva.

\section{Hellenism and classicism in the History}

Bossina, Luciano , 2009, 'Niketas Choniates as a Theologian' in Efthymiades and Simpson, ed. 2009, pp. 165-184.

Chaniotis, Angel os , 2009, 'Myths and Contexts in Aphrodisias' in Antike Mythen: Medien, Transformationen und Konstruktionen, edited by Ueli Dill , Christine Wald Ueli Dill , Christine Walde, de Gruyter, Berlin and New York, pp. 313-338.

Croke, Brian , 2010, 'Uncovering Byzantium's Historiographical Audience' in Macrides, ed. 2010, pp. 25-53.

Davis, John , 2010, 'Anna Komnene and Niketas Choniates 'Translated': The Fourteenth Century Byzantine Metaphrases' in Macrides, ed. 2010, pp. 55-70.

Efthymiades, Stephanos , 2009a, 'Niketas Choniates: The Writer' in Simpson and Efthymiades ed., 2009, pp. 35-58.

Efthymiades, Stephanos , 2009b, 'Greek and Biblical Exempla in the Service of an Artful Writer' in Simpson and Efthymiades ed., 2009, pp. 101-119.

Gaul, Niels , 2003, 'Andronikos Komneneos, Prinz Belthandros und der Zyklop: Zwei Glossen zu Niketas Choniates' Chronike diegesis' Byzantinische Zeitschrift 96, pp. 623-660.

Harris, Jonathan , 2014, Byzantium and the Crusades, 2nd edition, London.

Hinterberger, Martin , 2010, 'Envy and Nemesis in the Vita Basilii and Leo the Deacon: Literary Mimesis or Something More?' in Macrides ed., 2010, pp. 187-203.

Howlett, Jane , 1981, 'Some Classical Saints in the Russian Tradition' in Mullett and Scott, ed. 1981, pp. 172-178.

Hunger, Herbert , 1981, 'The Classical Tr adition in Byzantine Literature: The Importance of Rhetoric' in Mullett and Scott, ed. 1981, pp. 35-47. 
Kaldellis, An thony , 2007, Hellenism in Byzantium: The Transformation of Greek Identity and the Reception of the Classical Tradition, Cambridge University Press, Cambridge.

Kaldellis, Anthony , 2009, 'Niketas Choniates: Paradox, Reversal and the Meaning of History' in Simpson and Efthymiades, ed. 2009, pp. 75-99.

Kalligas, Haris A. , 2010, Monemvasia: A Byzantine City State, Routledge, London.

Kazhdan, Alexander P. , van Dieten , Jan-Louis, Maisano , Riccardo and Pontani, Anna, ed., 1994, Niceta Coniata: Grandezza e catastrophe di Bisanzio (Narrazione cronologica), vol. 1, Fondazione Lorenzo Valla, Milan.

Kinnamos, John , 1976, Deeds of John and Manuel Comnenus, translated by Charles M. Brand , Columbia University Press, New York.

Laiou, A. , 1991, 'The Foreigner and the Stranger in 12th Century Byzantium: Means of Propitiation and Acculturation' in Fremde der Gesellschaft: Historische und socialswissenschaftliche Untersuchungen zur Differenzierung von Normalität and Fremdheit, edited by M. T. Fögen , Frankfurt, pp. 71-97, reproduced in Byzantium and the Other: Relations and Exchanges, edited by Cécile Morrisson and Rowan Dorin , 2012, Ashgate, Farnham.

Macrides, Ruth , ed., 2010, History as Literature in Byzantium, Ashgate, Farnham.

Magoulias, Harry, 1984, O City of Byzantium, Annals of Niketas Choniates, Wayne State University Press, Detroit.

Maisano, Riccardo , 2000, 'I poemi omerici nell'opera sto rica di Nicetas Coniata' in Posthomerica II Tradizioni omeriche dall'Antichita al Rinascimento, edited by F. Mo ntanari and S. Pittaluga, Dipartimento di archeologica, filologia classica e loro tradizioni, Genova, pp. 41-53.

Maisano, Riccardo , 2006, 'La funzione letteraria della bibbia in Niceta Coniata' in Spirito e forme nella letteratura bizantina, edited by Antonio Garzya, Giannini Editore , Naples , pp. 47-64.

Mullett, Margaret , 2013, 'How to Criticize the laudandus ' in Power and Subversion in Byzantium: Papers From the Forty-Third Spring Symposium of Byzantine Studies, Birmingham, March 2010. Publications of the Society for the Promotion of Byzantine Studies, 17, edited by Dimiter Angelov and Michael Saxby , Ashgate, Farnham, pp. 247-262.

Mullett, Margaret and Scott, Roger, ed., 1981, Byzantium and the Classical Tradition, Centre for Byzantine Studies, University of Birmingham, Birmingham.

Page, Gill , 2008, Being Byzantine: Greek Identity Before the Ottomans, Cambridge University Press, Cambridge.

Papamastorakis, Titos , 2009, 'Interpreting the De Signis of Niket as Choniates' in Efthymiades and Simpson, ed. 2009, pp. 209-223.

Pontani, Anna , 2014, Niceta Coniata: Grandezza e catast rophe di Bisanzio, vol. 3, Fondazione Lorenzo Valla, Milan.

Saxey, Roderick , 2009, 'The Homeric Metamorphosis of Andronikos II Komnenos' in Efthymiades and Simpson, ed. 2009, pp. 121-143.

Scott, Roger , 1981, 'The Classical Tradition in Byz antine Historiography' in Mullett and Scott, ed. 1981, pp. 61-74.

Simpson, Alicia , 2006, 'Before and After 1204: The Versions of Ni ketas Choniates' Historia' Dumbarton Oaks Papers 60, pp. 189-221.

Simpson, Alicia , 2009, 'Introduction: Niketas Choniates: The Historian' in Simpson and Efthymiades, ed. 2009, pp. 13-34.

Simpson, Alicia , 2013, Niketas Choniates: A Historiographical Study, Cambridge University Press, Cambridge.

Simpson, Alicia and Efthymiades, Stephanos, ed., 2009, Niketas Choniates: A Historian and a Writer, Pomme d'Or, Geneva.

Ustinova, Yulia, 1999, The Supreme Gods of the Bosporan Kingdom: Celestial Aphrodite and the Most High God, Brill, Leiden.

van Dieten, Jan-Louis , 1975, Nicetae Choniatae historia (Corpus Fontium Historiae Byzantinae), vol. XI, 2 vols. de Gruyter, Berlin.

van Dieten, Jan-Louis and Pontani, Anna , 1999, Niceta Coniata: Grandezza e catastrophe di Bisanzio (Narrazione cronologica), vol. 2, Fondazione Lorenzo Valla, Milan. 


\section{The influence of the Old Testament}

Angold, Michael , 2003, The Fourth Crusade, Pear son, Harlow.

Biliarsky, Ivan , 2010, 'Old Testament Models and the State in Early Medieval Bulgaria, in Magdalino and Nelson 2010, pp. 255-277.

Bossina, Luciano , 2009, 'Niketas Choniates as a Theologian' in Efthymiades and Simpson, ed. 2009, pp. 165-184.

de Claisse-Walford, Nancy L. , Jacobson, Rolf A. , and LaNeel Tanner, Beth , ed., 2014, The Book of Psalms (New International Commentary on the Old Testament), Eerdmans, Michigan. Gouma-Peterson, Thalia , 2000a, 'Gender and Power: Passages to the Maternal in Anna Komnene's Alexiad' in Gouma-Peterson, ed. 2000, pp. 107-124.

Gouma-Peterson, Thalia, ed., 2000b, Anna Komnene and Her Times, Garland, New York. Hillers, Delbert R. , 1993, 'Lamentations and Sumerian Lam ents' in Metzger and Coogan, ed. 1993, p. 420.

Jeffreys, Elizabeth , 2010, 'Old Testament "History" and the Byzantine Chronicle' in Magdalino and Nelson, ed. 2010, pp. 153-174.

Krueger, Derek , 2010, 'The Old Testament and Monasticism\#x2019; in Magdalino and Nelson , ed. 2010, pp. 199-221.

Layman, Trevor , 2015, The Incineration of New Babylon: The Fire Poem of Konstantinos Stilbes, Pomme d'Or, Geneva.

Magdalino, Paul , ed., 1992, The Perception of the Past in Twelfth Century Europe, Bloomsbury, London.

Magdalino, Paul , 1993, The Empire of Manuel I Komnenos 1143-1180, Cambridge University Press, Cambridge.

Magdalino, Paul , 2000, 'The Pen of the Aunt: Echoes of the Mid-Twelfth Century in the Alexiad' in Gouma-Peterson , ed. 2000, pp. 15-43.

Magdalino, Paul , 2009, 'Prophecy and Divination in the History' in Simpson and Efthymiades ed., 2009, pp. 59-74.

Magdalino, Paul and Nelson, Robert S. , 2010a, 'Introduction' in Magdalino a nd Nelson, ed. 2010, pp. 1-38.

Magdalino, Paul and Nelson, Robert S. ed., 2010b, The Old Testament in Byzantium, Dumbarton Oaks, Washington, DC.

Magoulias, Harry, 1984, O City of Byzantium, Annals of Niketas Choniates, Wayne State University Press, Detroit.

Maisano, Riccardo , 2000, 'I poemi omerici nell'opera storica di Nicetas Coni ata' in Posthomerica II Tradizioni omeriche dall'Antichita al Rinascimento, edited by F. Montanari and S. Pittaluga, Dipartimento di archeologica, filologia classica e loro tradizioni, Genova, pp. 41-53.

Mango, Cyril , 1981, 'Discontinuity with the Classical Past in Byzantium' in Mul lett and Scott , ed. 1981, pp. 48-57.

Metzger, Bruce M. and Coogan, Michael David ed., 1993, The Oxford Companion to the Bible, Oxford University Press, Oxford.

Mullett, Margaret and Scott, Roger , ed., 1981, Byzantium and the Classical Tradition, Centre for Byzantine Studies, University of Birmingham, Birmingham.

Parpulov, Georgi R. 2010, 'Psalters and Personal Piety in Byzantium' in Magdalino and Nelson , ed. 2010, pp. 77-105.

Rapp, Claudia , 2010, 'Old Testament Models for Emperors in Early Byzantium' in Magda-lino and Nelson , ed. 2010, pp. 175-197.

Saxey, Roderick , 2009, 'The Homeric Metamorphosis of Andronikos II Komnenos' in Efthymia des and Simpson, ed. 2009, pp. 121-143.

Scott, Roger , 1981, 'The Classical Tradition in Byzantine Historiography' in Mullett and Scott , ed. 1981, pp. 61-74.

Simpson, Alicia , 2013, Niketas Choniates: A Historiographical Study, Cambridge University

Press, Cambridge.

Simpson, Alicia , and Efthymiades, Stephanos, ed., 2009, Niketas Choniates: A Historian and a Writer, Pomme d'Or, Geneva.

van Dieten, Jan-Louis , 1973, Orationes et Epistulae, de Gruyter, Berlin. 
van Dieten, Jan-Louis , 1975, Nicetae Choniatae historia (Corpus Fontium Historiae Byzantinae), vol. XI, 2 vols., de Gruyter, Berlin.

van Dieten, Jan-Louis and Pontani, Anna , 1999, Niceta Coniata: Grandezza e catastrophe di Bisanzio (Narrazione cronologica), vol. 2, Fondazione Lorenzo Valla, Milan.

\section{Niketas on the emperors}

Garstad, Benjamin , 2012, Apocalypse Pseudo-Methodius and An Alexandrian World Chronicle, Harvard Unive rsity Press, Cambridge, MA.

Kaldellis, Anthony , 2009, 'Niketas Choniates: Paradox, Reversal and the Meaning of History' in Simpson and Efthymiades, ed. 2009, pp. 75-99.

Laiou, A. , 1991, 'The Foreigner and the Stranger in 12th Century Byzantium: Means of Propitiation and A cculturation' in Fremde der Gesellschaft: Historische und socialswissenschaftliche Untersuchungen zur Differenzierung von Normalität and Fremdheit, edited by M. T. Fögen , Frankfurt, pp. 71-97, reproduced in Byzantium and the Other: Relations and Exchanges, edited by Cécile Morrisson and Rowan Dorin, 2012, Ashgate, Farnham. Magdalino, Paul , 1993, The Empire of Manuel I Komnenos 1143-1180, Cambridge University Press, Cambridge.

Magdalino, Paul , 2009, 'Prophecy and Divination in the History' in Simpson and Efthymiades , ed. 2009, pp. 59-74.

Magdalino, Paul and Nelson, Robert S. , ed., 2010, The Old Testament in Byzantium, Dumbarton Oaks, Washington, DC.

Magoulias, Harry , 1984, O City of Byzantium, Annals of Niketas Choniates, Wayne State University Press, Detroit.

Simpson, Alicia , 2006, 'Before and After 1204: The Versions of Niketas Choniates' Historia' Dumbarton Oaks Papers 60, pp. 189-221.

Simpson, Alicia , 2009, 'Introduction: Niketas Choniates: The Historian' in Simpson and Efthymiades, ed. 2009, pp. 13-34.

Simpson, Alicia , 2013, Niketas Choniates: A Historiographical Study, Cambridge University Press, Cambridge.

Simpson, Alicia and Efthymiades, Stephanos , ed., 2009, Niketas Choniates: A Historian and a Writer, Pomme d'Or, Geneva. van Dieten, Jan-Louis, 1975, Nicetae Choniatae historia (Corpus Fontium Historiae Byzantinae), vol. XI, 2 vols., de Gruyter, Berlin. van Dieten, Jan-Louis and Pontani, Anna, 1999, Niceta Coniata: Grandezza e catastrophe di Bisanzio (Narrazione cronologica), vol. 2, Fondazione Lorenzo Valla, Milan. 